\title{
Life in an English Jail
}

\author{
Gerry Mackin \\ H Block 7, Long Kesh
}

On arriving at the Kesh in August 1995, I was expecting the familiar set up as is found in every jail in England: come through reception; strip search; get your towel, sheets, cup, knife, and fork; and be shown to whichever cell the screws decide to put you in for the duration of your stay. Often you will find yourself to be the only republican prisoner in the jail, and while many of the ordinary English prisoners will be supportive, at the end of the day you can only depend on yourself in the constant battle to survive. However, this was not to be the case in Long Kesh. I was totally taken aback by the surroundings and the warm atmosphere created by the lads here in the blocks. Besides the conditions, the fact that we are not isolated from each other makes the blocks the complete opposite to conditions under which fellow POWs in English jails have to endure.

By far the biggest problem for all POWs in any jail is trying to maintain some sort of contact with their families and friends. This problem is compounded a hundredfold in England. All visitors, even close relatives, have to wait anywhere between three and nine months before the Home Office will grant them security clearance to visit the POW. Prior to such clearance, a closed visit (i.e. no physical contact) may be arranged at the discretion of the prison governor. However the inhuman conditions under which such visits are conducted, with the POW never able to touch or hug his loved ones, means that POWs generally refuse these visits. Often, even close relatives will be refused security clearance and thus visits with them will be impossible. When clearance does finally come through, that is the start of more problems.

Since most of the jails in which POWs are kept in England are out in the country and off the beaten track, journeys to them from Ireland are not only long but are complicated by many changes of transport on the way. This adds to the problems of journey time and cost. As a result, most POWs only receive visits twice or less each year. Visitors also have to run the gauntlet of security checks at port or airport terminals; often being stopped, questioned, arrested, threatened. They also suffer the constant threat of deportation under the Prevention of Terrorism Act (PTA) whereby they know they will never be able to visit their loved ones in England again. Once they reach the jail, they may be faced with petty indignities and the bigotry of the screws. They may find the visit disrupted, cut short or even cancelled due to the vindictiveness of the prison regime. Worse still, they may find that the POW has just been 'ghosted' hundreds of miles away to another jail without their being informed. In such cases, often all they can do is return home without the visit.

Visits themselves are never private but are under the constant eye of screws and cameras, and they are often recorded. Physical contact is also curtailed 
between visitors and POWs. As a result, visits are often conducted under conditions of extreme tension, which is further compounded by the fact that visitors know they have to make the same long journey home, facing the harassment and intimidation again and the debts accrued to pay for the journey.

Since the ceasefire was announced in August 1994, Irish POWs in English jails have witnessed a marked deterioration in conditions, particularly in relation to visits. After the Whitemoor escape in September 1994, closed family and legal visits were forced on the prisoners involved. Then in June 1995, these closed visits were extended to cover all POWs being held in what are called Special Secure Units (SSUs) at Whitemoor and Belmarsh. The POWs have refused to accept these conditions, and as a result, many have not had a visit for the past eighteen months.

Officially, contact between prisoners and their families is encouraged by the British government. Britain has also adopted the Ferrers Report (1992) and the European Convention on the Transfer of Prisoners (1983), both of which advocate the placing of prisoners in jails (and in countries) closer to their families. However, the British have continually placed barriers in the way of republican POWs to prevent them being moved to jails in Ireland closer to their families. Anyone who has been transferred to Ireland to date has only achieved that transfer through the pressure of legal or protest action. Despite the peace process and the ratification of the European Convention by the 26 county government last summer, not one republican POW has been repatriated to the 26 counties to date (February, 1996). About a dozen POWs also remain in Britain because they have been refused transfers to the North. Among these are the five Irish prisoners currently being held under appalling conditions (22hour lock-up, closed legal and family visits) in Belmarsh jail, London. They are Liam McCotter, Liam O'Duibhir, Danny McNamee, Peter Sherry, and Dingus Magee (who is also on protest).

When it comes to the issues of family illness or death, it becomeseven clearer that the prevention of links between POWs in England and their families is part of a deliberate and vindictive policy practised by the British government. No Irish POW in England will be allowed compassionate parole to visit a seriously ill family member or to attend their funeral in the event of a death. Since the ceasefire, both Brendan Dowd (Whitemoor) who has served 21 years in jail, and Pat Magee (on temporary transfer to Maghaberry) have been refused parole to attend the funerals of their mother and father respectively. The same has happened prior to the ceasefire for many other POWs in English jails from the 1970s right through to the 1990s. No Irish POW in England will be granted compassionate parole for any reason.

Phones have been introduced to all English high-risk jails over the past three to four years. These are a great boon to Irish POWs in particular who have very few visits. However, they are highly restricted and restrictions have increased in the past year. POWs are only allowed to phone people who have been previously cleared as visitors by the Home Office and all such calls are recorded. Limitations have also been placed on the amount of phone cards that 
can be bought, which is particularly disadvantageous to POWs phoning the 26 counties. Attempts have also been made to link the buying of phone cards to money earned from doing prison work etc., and to 'good behaviour.' Besides phone cards, POWs in English jails also depend heavily on the mail to keep in contact with family and friends. The delay or 'loss' of mail is a favourite tactic of the prison authorities to harass POWs when it suits.

One of the major problems associated with jail in England is 'ghosting.' At about 6:30 am in the morning, often on the morning of a visit and with no prior warning, a prisoner's cell door will be opened and he will he told he has ten minutes to get ready, he is on the move. He will not be told where he is going until he arrives at the next jail several hundred miles away. Neither will his family be informed where he is going, even should they arrive at the prison gate for a visit. He will be strip-searched and told to wear prison uniform. POWs tend to refuse the prison gear and travel naked and handcuffed in the cubicle of the armoured lorry or 'horse box' as it is known. The journey often lasts from seven o'clock in the morning until five in the evening with maybe a stop off in the punishment block of some jail while the screws get their lunch. In this block, the naked POW may be subjected to taunts or harassment from the local screws. The prisoner will not be allowed to bring any belongings with him. These will arrive along with phone cards and any money he has in the shop a month or so later. As a result, ghosted POWs will have to borrow clothes, phone cards, and so on from other prisoners. Often, a lot of his belongings never arrive, having been 'lost.' Delays in money arriving also prevent POWs from buying stamps and phone cards, the main methods for keeping in touch with families. Ghosting has a very unsettling effect on long-term POWs and their families and is used as a punishment to disrupt friendship circles, routines, education, or planned visits. It is akin, on a grander scale, to the way red book POWs in the Kesh were moved around from block to block on a regular basis.

Life in jail in England is much different from life in jail in Long Kesh at the present time. It is much more akin to the film version of what life in jail is like. Republicans there find themselves in jails with few or even no other republicans. In a jail of 800 there may be only half a dozen at the most. Due to the stand of the first republican POWs in the 1970s and since, most ordinary English prisoners respect republican POWs and many build up friendships and show solidarity with them. However, jail culture in England is much different from here. One of the biggest problems in English jails is the drugs problem and the other problems this spawns. Most ordinary prisoners in England are on drugs of one form or another. The taking of hard drugs such as heroin and crack is widespread. Most of the violence among prisoners in English jails (stabbings, beatings, etc.) occurs as a result of drugs: inability to pay drug debts, different sellers impinging on others territories, and so on. The same could be said for most of the theft among prisoners, which is an everyday occurrence as addicts try to get valuables to exchange for drugs. 
Prisoners do come together in solidarity to protest at conditions in the jails in England and Irish POWs will usually be to the fore in such protests. As a result of such actions, Irish POWs have earned a lot of respect over the years from other prisoners in the high-security jails. Protests occur regularly and Irish POWs have been through the lot to bring about better conditions. Some have experienced years living in punishment blocks in solitary confinement being denied visits and suffering beatings at the hands of screws. Over the years, protests in which Irish POWs have been involved have often been linked to general prison conditions affecting all prisoners within the jail, i.e., food, visiting facilities, and so on. However, Irish POWs have also been involved in protests which have specifically affected them, in particular over the issue of transfer. Two POWs, Michael Gaughan and Frank Stagg, died while on hunger strike over this issue during the 1970s.

As we write this article, Paul Dingus Magee is now on blanket protest in Belmarsh jail,London. Dingus, like four other Irish prisoners, Liam McCotter, Liam O Duibhir, Peter Sherry, and Danny McNamee, has been without visits for the past year-and-a-half. Paddy Kelly and Mick O'Brien were moved out of the special secure unit at Whitemoor after a prolonged protest against conditions. Due to tireless campaigning and massive international pressure, Paddy has now been transferred to Portlaoise Prison. However, he is dying of cancer, at least in some part due to neglect while in prison in England. Along with this, ten POWs are now into their twenty-first year of imprisonment in England.

As I wrote at the start of this article, things have very much changed since I arrived here in Long Kesh. We can receive family visits each week and phone home 24 hours a day if required. This means a lot for our families. The children can come to visit each week, smiling and laughing, telling fathers of everyday things like how school is going. It may not seem like much but if you are one of the families who had or have a relative in an English jail it means a lot. Our thoughts are with the POWs in England and their families who face torment and torture now as we speak.

\section{THE LONGEST SERVING POWS}

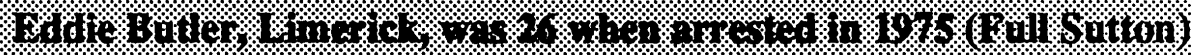

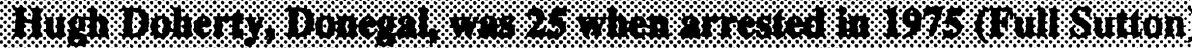

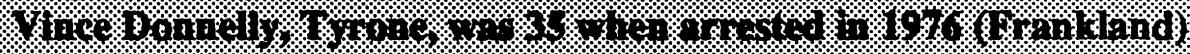

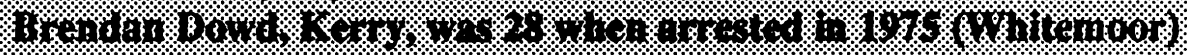

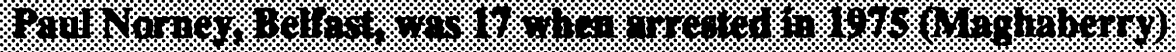

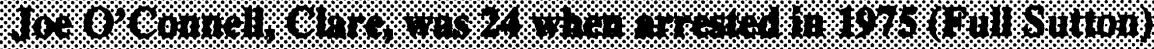

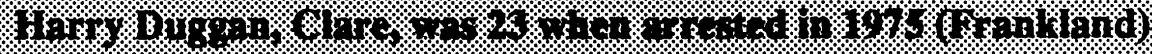




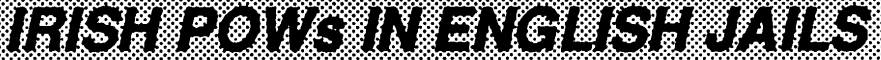

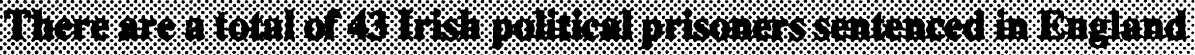

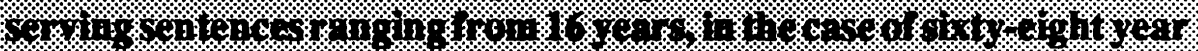

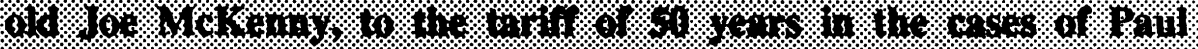

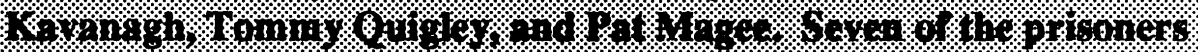

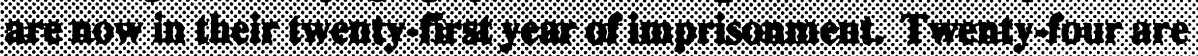

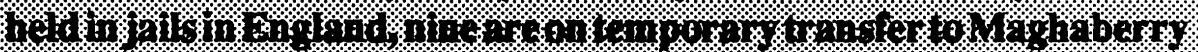

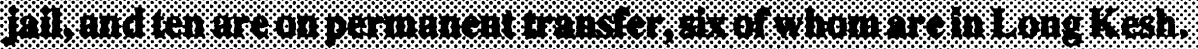

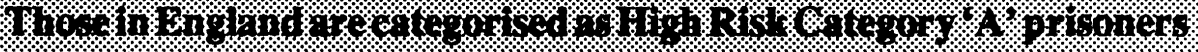

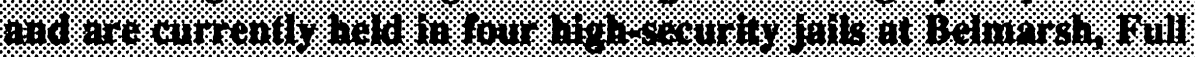

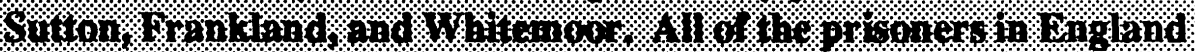

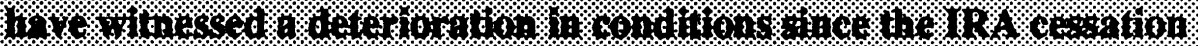

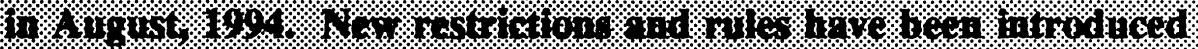

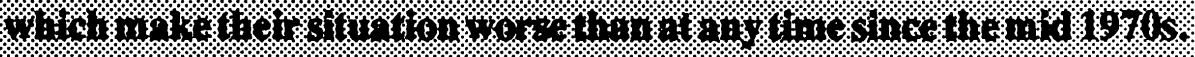

\section{SPECIAL SECURE UNITS}

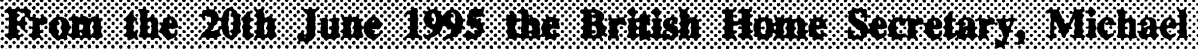

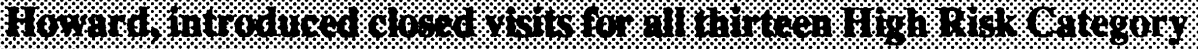

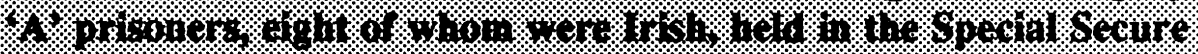

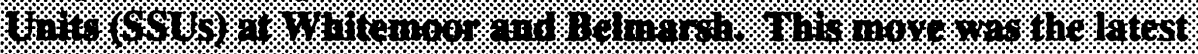

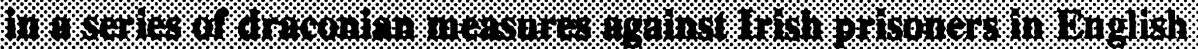

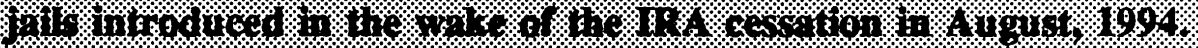

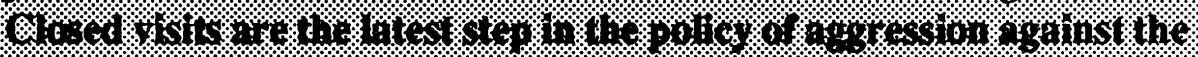

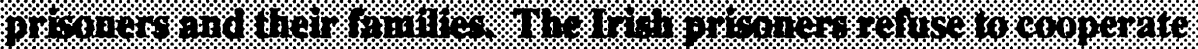

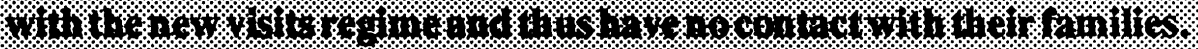

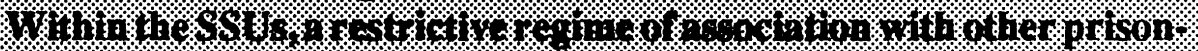

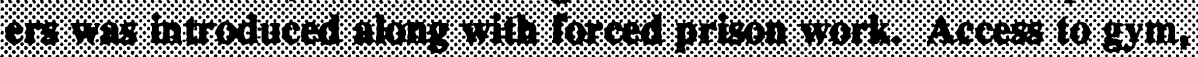

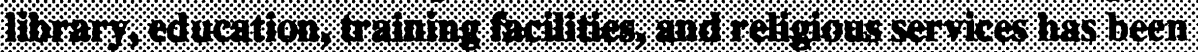

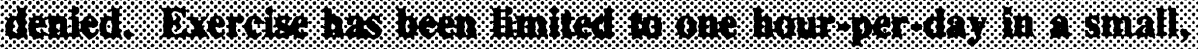

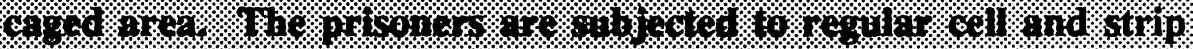

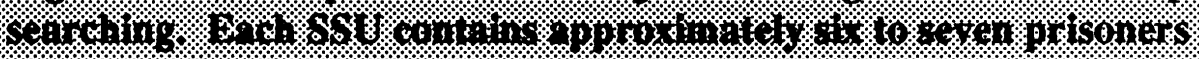

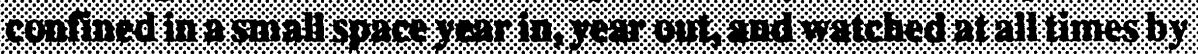

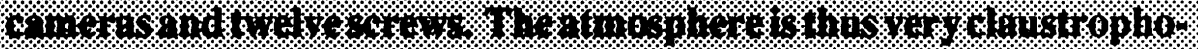

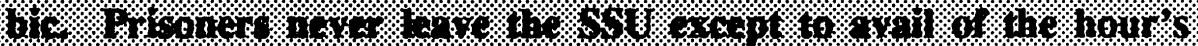

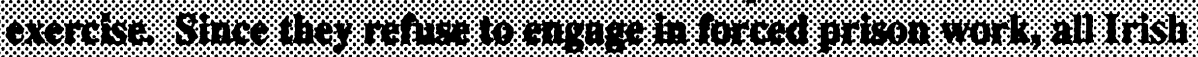

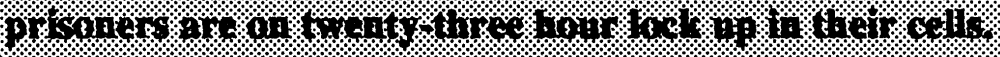

